\title{
INFLUENCE DU TRAITEMENT TECHNOLOGIQUE DE LA CÉRÉALE SUR LE MÉTABOLISME DE L'URÉ DANS LE HUMEN DU MOUTON
}

\author{
Michelle DURAND \\ Laboratoire de Recherches sur la Conservation et l'Efficacité des Aliments, \\ Centre national de Recherches zootechniques, I. N.R. A., \\ 78 - Jouy-en-Josas
}

Afin d'améliorer la valeur azotée de l'urée, deux moyens sont proposés :

a) échelonner l'uréolyse au niveau du rumen par une technique appropriée d'enrobage ;

b) assurer une libération plus rapide au niveau du rumen de l'énergie indispensable à la protéosynthèse bactérienne à partir du N-uréique, par un traitement hydro-thermique de la céréale.

Une expérience récente de $Z_{\text {ELTER }}$ et al. (1) a montré que la déshydratation d'une orge immature améliorait significativement par rapport à l'ensilage l'utilisation métabolique de l'azote uréique chez le taurillon; par contre, le traitement par enrobage de l'urée, expérimenté dans le cas de l'ensilage, était sans action à ce niveau. Pour expliquer ces phénomènes, nous avons suivi l'évolution postprandiale de certains métabolites azotés et glucidiques dans le rumen de moutons recevant des régimes similaires.

\section{I. - En présence d'urée non traitée}

Avec la céréale déshydratée et par comparaison avec l'ensilage de cette même céréale :

a) les concentrations ruminales de $\mathrm{NH}_{3}$ sont moins élevées (pic à $34 \mathrm{mg} \mathrm{N}-\mathrm{NH}_{3}$ p. $100 \mathrm{ml}$ contre 54) et décroissent plus rapidement (valeurs initiales retrouvées en 3 heures contre 5 heures) ; ce métabolite provient essentiellement de l'urée et non de la protéine de l'orge comme c'est le cas pour l'ensilage ;

b) l'urémie postprandiale est plus basse de $20 \mathrm{p}$. Ioo, ce qui indiquerait que la fuite de $\mathrm{NH}_{3}$ à travers la paroi du rumen est beaucoup plus réduite ;

c) la libération de glucides à courtes chaînes est plus massive et plus rapide (au temps 30 minutes, $240 \mathrm{mg}$ p. roo $\mathrm{ml}$ contre 82) ; elle est concomitante au pic ammoniacal ; avec l'ensilage, par contre, elle ne devient notable (temps 5 heures : $140 \mathrm{mg}$ p. I00 ml) que lorsque les concentrations ammoniacales sont retombées à leur niveau initial ;

d) la répartition des acides gras volatils est différente : augmentation du pourcentage d'acide propionique (3I p. IOO des AGV contre 22), baisse de celui de l'acide butyrique $\{9,7 \mathrm{p}$. Ioo contre I5,2), phénomènes pouvant être reliés à la plus forte acidification du milieu (pH 5,5 contre 6,0$)$.

\section{2. - En présence d'urée enrobée}

Les différences concernant l'ammoniogenèse suivant le mode de traitement de la céréale sont ici plus accentuées : avec l'ensilage le pic ammoniacal est important (50 $\mathrm{mg} \mathrm{N}$ p. 1oo ml) suivi d'une décroissance lente (au temps 5 heures, les valeurs sont encore supérieures aux valeurs initiales) par contre, avec l'orge déshydratée l'ammoniogenèse est extrêmement réduite : pic à $20 \mathrm{mg} \mathrm{N}$ p. Ioo $\mathrm{ml}$, valeurs initiales retrouvées aux 90 minutes ; le $\mathrm{NH}_{3}$ serait ici utilisé au fur et à mesure de sa formation. 
L'ensemble de ces résultats confirme qu'avec la déshydratation de la céréale immature la micropopulation du rumen dispose de l'énergie et des chaînes carbonées nécessaires à la transformation de la majeure partie du $\mathrm{N}$-uréique en protéine bactérienne.

Des expériences en cours indiqueront si des résultats similaires peuvent être obtenus avec des céréales mûres ayant subi un traitement approprié.

\section{SUMMARY}

\section{UREA METABOLISM IN THE SHEEP RUMEN AS INFLUENCED} BY THE, TECHNOLOGICAI, TREATMENT OF THE CEREAL

Two methods are proposed to improve the nitrogen value of urea :

a) decreasing the rate of ureolysis in the rumen by a suitable technique of coating ;

b) a hydro-thermic processing of the cereal providing more rapid release in the rumen of the energy necessary for the bacterial proteosynthesis from the urea nitrogen.

ZELTER et al. recently showed that, in comparison with silage, dehydration of immature barley significantly improves the metabolic utilization of the urea nitrogen in the bullock; on the other hand, the treatment of urea by coating, experimented in the case of silage, did not have any effect at this level. In order to explain these phenomena, we studied the postprandial evolution of some nitrogenous and glucidic metabolites in the rumen of sheep receiving similar diets.

\section{I. - In presence of untreated urea}

When dehydrated cereal is fed, as compared to silage, we noticed that:

a) the ruminal $\mathrm{NH}_{3}$ concentrations are not so high (peak at $34 \mathrm{mg} \mathrm{N}-\mathrm{NH}_{3} \mathrm{p}$. $100 \mathrm{ml}$ versus 54) and decrease more rapidly (initial values recovered in 3 hours versus 5 hours) ; this metabolite mainly comes from urea and not from the barley protein as in the case of silage ;

b) the postprandial uremia is lower (20 p. I0o), indicating a reduced loss of $\mathrm{NH}_{3}$ through the rumen wall ;

c) the release of short chain carbohydrates is mure important and rapid (after $3^{\circ}$ minutes $24^{\circ} \mathrm{mg} \mathrm{p}$. Ioo $\mathrm{ml}$ versus 82 ); it is concomitant to the ammonia peak; in the case of silage, this release only becomes notable (after 5 hours : $1_{4} 0 \mathrm{mg}$ p. Ioo $\mathrm{ml}$ ) when the concentrations of ammonia have declined to their initial level;

d) the distribution of the volatile fatty acids is different : increase of the percentage of propionic acid (3I p. Ioo of the VFA versus 22) and decrease of the butyric acid (9.7 p. 100 versus 15.2), phenomena which can be related with the higher acidification of the medium ( $\mathrm{pH} 5.5$ versus 6.0$)$.

\section{2. - In presence of coated urea}

The differences in the ammoniogenesis are very pronounced according to the mode of treatment of the cereal : with silage the ammonia peak is important ( $50 \mathrm{mg} \mathrm{N} \mathrm{p}$. I00 ml) followed by a slow decrease (after 5 hours, the values are still higher than the initial ones); on the other hand, with dehydrated barley, the ammoniogenesis is very reduced : peak at $20 \mathrm{mg} \mathrm{N}$ p. roo $\mathrm{ml}$, initial values recovered after 90 minutes ; in this case, $\mathrm{NH}_{3}$ is probably used as soon as it is produced.

All these results confirm that when the immature cereal is dehydrated, energy and carbon chains are available for the conversion of main part of the urea- $\mathrm{N}$ into bacterial protein.

Experiments in progress will show if similar results can be obtained with mature cereals having been submitted to a suitable treatment.

(i) Zelter S. Z., Charlet-Léry Geneviève, ig69. C. R. A. Acad. Sci,, Paris, 269, iooj. 